\title{
Working
}

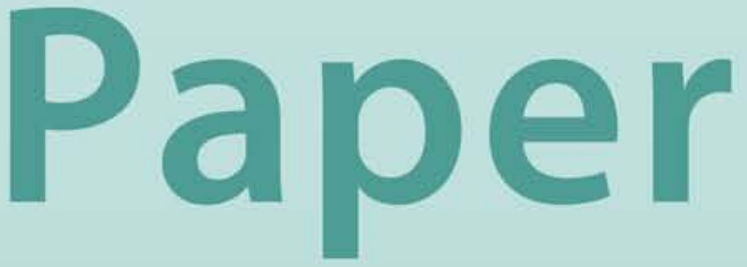


Contagion, Monsoons, and Domestic Turmoil in Indonesia: A Case Study in the Asian Currency Crisis

Valerie Cerra and Sweta Chaman Saxena 


\title{
IMF Working Paper
}

\author{
European I Department
}

\section{Contagion, Monsoons, and Domestic Turmoil in Indonesia: A Case Study in the Asian Currency Crisis}

\author{
Prepared by Valerie Cerra and Sweta Chaman Saxena ${ }^{1}$ \\ Authorized for distribution by Sharmini Coorey
}

March 2000

\begin{abstract}
The views expressed in this Working Paper are those of the author(s) and do not necessarily represent those of the IMF or IMF policy. Working Papers describe research in progress by the author(s) and are published to elicit comments and to further debate.
\end{abstract}

This paper investigates whether Indonesia's recent currency crisis was due to domestic fundamentals, common external shocks ("monsoons"), or contagion from neighboring countries. Markov-switching models attribute speculative pressure on Indonesia's currency to domestic political and financial factors and contagion from speculative pressures in Thailand and Korea. In particular, the results from a time-varying transition probability Markov-switching model (which overcomes some drawbacks of previous methods) show that inclusion of exchange rate pressures from Thailand and Korea in the transition probabilities improves the conditional probabilities of crisis in Indonesia. There is also evidence of contagion in the stock market.

JEL Classification Numbers: F39, F41, F42, F49, C32, G15

Keywords: Currency crisis, Contagion, Indonesia, Markov-switching models

Authors' E-Mail Addresses: vcerra@imf.org; ssaxena+@pittedu

${ }^{1}$ European I Department, IMF; and University of Pittsburgh, respectively. This paper was presented at The Asian Crisis Conference held in December 1998 at the University of Washington, Seattle, WA. The authors would like to thank Simeon Djankov for providing the data on political confidence and Chang-Jin Kim for assistance with econometric issues and programs. The authors are also grateful for helpful comments from Stijn Claessens, Simeon Djankov, Charles Engel, Cheng Hsiao, Keon Lee, Paul Masson, Kar-yiu Wong, Eric Zivot, and anonymous referees. All errors are, however, ours. 


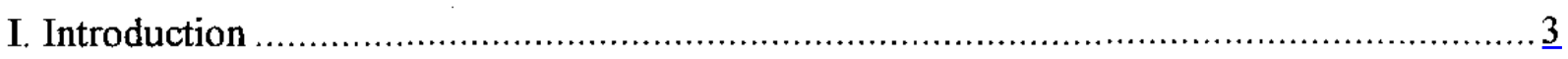

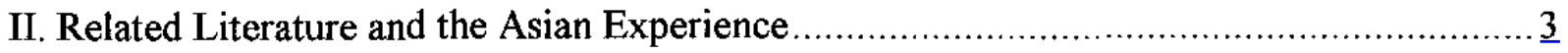

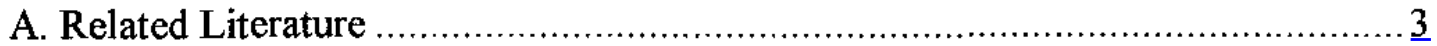

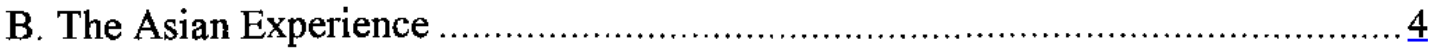

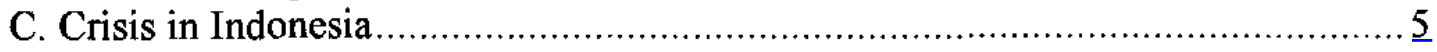

III. Econometric Evidence of Contagion in Currencies .......................................... $\underline{5}$

A. The Equilibrium Real Effective Exchange Rate .................................. $\underline{\mathbf{5}}$

B. Measure of Exchange Rate Pressure .................................................. $\underline{6}$

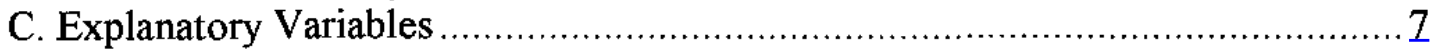

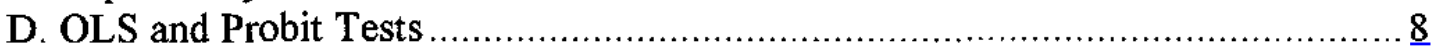

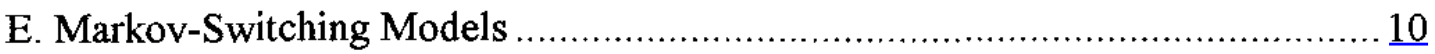

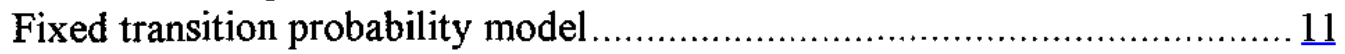

Time-varying transition probability model with regional contagion ............. 12

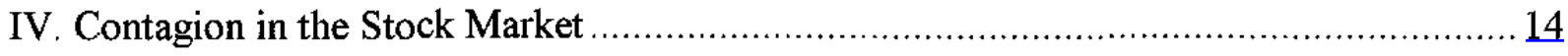

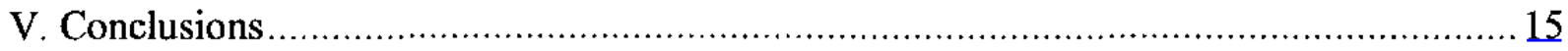

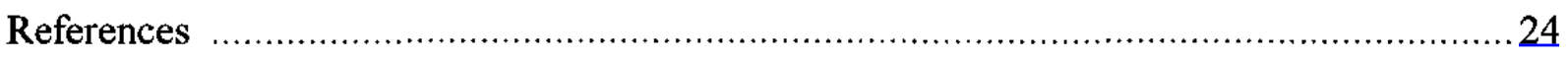

Appendices

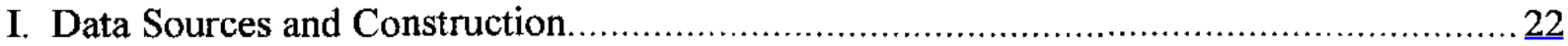

II. Construction of "Forecasted Values" for the Markov Switching Models ..................... $\underline{23}$

Tables

1. Results from Ordinary Least Squares and Probit Models .................................... 16

2. Results from Markov-Switching Models ...................................................... 17

Figures

1. Probabilities and Forecasts for Indonesia's Market Pressure Index: FTP MSM ............ 18

2. Probabilities and Forecasts for Indonesia's Market Pressure Index: TVTP MSM ......... 19

3. Probabilities and Forecasts for Indonesia's Stock Market Index: FTP MSM ................20

4. Probabilities and Forecasts for Indonesia's Stock Market Index: TVTP MSM............. 21 


\section{INTRODUCTION}

This decade has witnessed currency crises in many parts of the world. The decade began with the ERM breakdown in 1992, followed by the Mexican crisis in 1994, which spread to Latin America. Yet, the magnitude of the 1997 crisis in South East Asia, which engulfed countries like Thailand, Indonesia, Malaysia, South Korea and the Philippines was unexpected by most observers. Indeed, Asia had been praised as a miracle for its outstanding growth performance since the late 1980 s and early $1990 \mathrm{~s}$; some of the economies involved in the crisis had earned the title of "Asian Tiger". These Asian economies were consistently praised for their openness, and the economies prospered as liberalization drives led to large inflows of capital.

Following the crisis that began in July 1997, economists have begun to look more closely at the underlying fundamentals. High growth rates of the Asian economies contributed to an underestimation of risks from weak financial systems, questionable political governance, and an over-reliance on external debt. In addition to these domestic factors, some economists have argued that there were common external shocks that contributed to the crisis. Finally, there are new models of currency crises, which emphasize contagion through multiple equilibria or a "wake-up call" to investors. ${ }^{2}$

This paper focuses on the case of Indonesia, and tries to separate the contributions of economic fundamentals from contagion in the development of events. Indonesia has been selected as the country of interest because it suffered the most severe economic consequences in the year following the onset of the crisis as measured by the magnitude of currency depreciation and contraction of economic activity. This outcome occurred despite macroeconomic fundamentals leading up to the crisis that are believed to have been among the strongest of the crisis countries. Indonesia could be arguably one of the clearest cases of contagion from neighboring countries. ${ }^{3}$ The rest of the paper is structured as follows. Section II provides a brief overview of related literature and discusses developments in Asia and Indonesia. In Section III, we construct a measure of the degree of speculative pressure on the exchange rate, a Market Pressure Index, and use Markov-switching models to identify the roles of economic fundamentals and contagion in the crisis. Section IV presents some evidence on contagion in the stock market. Finally, Section V concludes.

\section{RELATED LITERATURE AND THE ASIAN EXPERIENCE}

\section{A. Related Literature}

\footnotetext{
${ }^{2}$ Corsetti, Pesenti, and Roubini (1998a) propose these arguments. Masson (1998) provides a framework for grouping causes of a crisis into common shocks, spillover effects, and (pure) contagion. We employ his terminology of "monsoons" to refer to common external shocks.

${ }^{3}$ Radelet and Sachs (1998a) support this view.
} 
Previous episodes of currency crises tended to stem from unsustainable fiscal deficits financed by seigniorage or were induced by a trade-off between short-run macroeconomic flexibility and longer-term credibility. The first generation of currency crisis models such as Krugman (1979) and Flood and Garber (1984) fit the experience of Latin American crises in response to monetization of debt from unsustainable fiscal imbalances. The secondgeneration models explained the crises as self-fulfilling outcomes. Diamond and Dybvig (1983) present a stylized model of financial intermediation in which there are multiple equilibria that depend on agents' confidence in the solvency of banks. Obstfeld (1986) fits the experience of European countries in the early 1990s as it emphasizes the tension between the government's motives to defend an exchange rate peg or abandon it to reduce unemployment.

New generation models of currency crisis emphasize financial sector weaknesses, and investor behaviors. Goldfjan and Valdes (1997) focus on the effects of exogenous shocks to financial intermediaries that provide liquidity services. Agenor and Aizenman (1997) analyze the transmission process of contagious shocks by capturing the imperfections on both world capital markets and domestic credit markets. Krugman (1998) and Corsetti, et al (1998b) explain the Asian crisis using moral hazard models. Froot, Scharfstein and Stein (1992) emphasize rational herding or multiple equilibria resulting from imperfect information; similarly, Calvo (1995) shows that herding behavior can be explained in the context of costly information and diversification opportunities.

The empirical literature on contagion has frequently focused on showing statistically significant correlations in financial asset prices or capital flows. Calvo and Reinhart (1996) find that weekly returns on equities and Brady bonds in Latin America are strongly correlated, more so after the Mexican crisis than before. Frankel and Schmuckler (1997) use country funds data to show that the Mexican crisis had a significant negative spillover effect on other Latin American countries. They suggest that institutional factors could potentially explain the high correlation. Research that tries to provide explicit reasons for the observed co-movements of financial flows or prices include Calvo, Leiderman and Reinhart (1993). They use VAR estimation to show that common external factors can largely explain capital inflows into several Latin American countries in the early 1990s. Valdes (1996) finds a strong correlation in the residuals of secondary market debt prices and credit ratings of Latin American countries after regressing these series on a set of domestic fundamentals. $\mathrm{He}$ attributes the residual contagion to the liquidity needs of international investors. Eichengreen, Rose and Wyplosz (1996) use probit estimation for a group of 20 industrialized countries and show that currency crises are related to the presence of trade channels between the countries, but they can not dismiss the possibility of contagion as well.

\section{B. The Asian Experience}

The Asian crisis exhibited no signs of predictability based on traditional first and second generation crisis models. Government deficits and inflation were low, unemployment was not a significant problem, capital inflows continued, and credit ratings were high. The crisis has been attributed mainly to excesses in the financial sector, which -combined with 
poor supervision and lax accounting standards-led to the collapse of a speculative bubble. The prolonged maintenance of pegged exchange rates and record of high economic growth rates encouraged massive inflows of capital. Poor financial sector supervision and weak prudential regulations allowed excessive lending, much of it directed toward real estate, construction, stock purchase and consumer loans. The ratio of short-term debt to foreign exchange reserves rose to high levels prior to the crisis. While this indicated vulnerability to a crisis, it did not guarantee the onset of one. Furthermore, these vulnerability indicators were ignored since the economies had sustained high rates of economic growth. When investors lost confidence in the economy and currency, the ensuing depreciation and rise in interest rates led to bankruptcies of banks and finance companies as loans soured. ${ }^{4}$

\section{Crisis in Indonesia}

Despite Indonesia's own internal problems, which included under-supervised banks, extensive crony capitalism, corruption, monopoly power and growing short-term debt, this country has been viewed as the clearest case of contagion, as it had the least severe macroeconomic imbalances. ${ }^{5}$ Indonesia's current account deficit was the lowest of the Asian-5 and export growth in 1996 was the second highest. The budget surplus averaged over one percent in the previous four years, while credit growth was modest. In short, the crisis in Indonesia does not appear to have been caused by poor traditional economic fundamentals. The crisis appears to relate to a weak financial sector and political uncertainty, combined with contagion from economies in the region. ${ }^{6,7}$

\section{ECONOMETRIC EVIDENCE OF CONTAGION IN CURRENCIES}

\section{A. The Equilibrium Real Effective Exchange Rate}

One plausible contributing factor to the attack could be that the Rupiah had become overvalued relative to its "equilibrium" level. This section looks for indications that overvaluation had occurred. The equilibrium real effective exchange rate (REER) is defined here as the permanent or trend component. If the REER is stationary, the permanent component consists of a single point or a point on a time trend depending on the absence or

${ }^{4}$ See Berg (1998), Kochhar, et al (1998), Corsetti, et al (1998a), and Radelet and Sachs (1998a) for overviews of the origins, onset, and spread of the Asian crisis.

${ }^{5}$ See Radelet and Sachs (1998a) for detailed arguments supporting this view.

${ }^{6}$ For more details about Indonesia's economic background, see Cerra and Saxena (1998).

${ }^{7}$ Indonesia was awarded the title of the "most corrupt country in Asia" in March 1997, according to the private Hong Kong-based Political and Economic Risk Consultancy survey of expatriate businessmen operating in various Asian countries. For specific examples of political instability and controversies, see Saxena (1998). 
presence of a deterministic trend, respectively. If the REER is nonstationary, the equilibrium value is the stochastic trend component. The REER is defined to be over/undervalued by the extent to which its value deviates from this permanent component. If the REER had moved temporarily above its equilibrium just prior to the onset of the crisis, the subsequent depreciation could be explained as a sudden reversal of this cyclical and unsustainable deviation. Moreover, the magnitude of the reversal could be compared to the initial deviation as an indication of overshooting.

Relative to its sample mean, a fitted time trend, and a trend created by a HodrickPrescott filter, the REER was undervalued by 21 percent, overvalued by 22 percent, and overvalued by 4 percent, respectively, in 1996; the REER was undervalued by 26 percent, overvalued by 21 percent, and undervalued by $1 \frac{1}{2}$ percent, respectively, in 1997 . These measures assume that the REER is stationary or trend stationary. However, unit root tests suggest that the REER is nonstationary. Therefore, we also used the methodology of Montiel (1997b), according to which the equilibrium REER is the steady state value of the REER. This concept of equilibrium represents a point of both internal and external balance and is a function of exogenous and policy variables such as the composition of government spending, commercial policy, terms of trade, and productivity growth in the traded goods sector. Given that these variables and the REER are found to be non-stationary, the equilibrium REER represents their common stochastic trend. We estimated the equilibrium REER using the Johansen reduced rank vector auto regression maximum likelihood estimation. The equilibrium value is constructed as the fitted value of the cointegrating equation between the REER and the fundamental economic determinants discussed above. On the basis of this method, the REER was overvalued by 13 and 27 percent on average in 1996 and 1997 , respectively. These results suggest that there was scope for exchange rate correction, but does not explain the actual depreciation of more than twice that amount. Therefore, the analysis continues by decomposing the causes of the pressure on the exchange rate into domestic and external fundamentals and contagion.

\section{B. Measure of Exchange Rate Pressure}

The term "crisis" in this paper refers to an intense increase in speculative pressure on the country's currency. Therefore, we construct a measure of exchange rate pressure, termed the Market Pressure Index (MPI), as follows:

$M P I_{i, t}=\frac{\left(\% \Delta e_{i, t}\right)}{\sigma_{\Delta e_{i, t}}}+\frac{\left(\Delta i_{i, t}\right)}{\sigma_{\Delta i_{i, t}}}-\frac{\left(\% \Delta r_{i, t}\right)}{\sigma_{\Delta \eta_{i, t}}}$

where e is the U.S. dollar exchange rate (domestic currency/US\$) and the changes in the exchange rate, interest rate and reserves are weighted by their respective standard 
deviations. ${ }^{8}$ This index is high when there is pressure on the currency and low otherwise. The intuition is that if there is an attack on the currency, either the exchange rate would depreciate, interest rates would be raised to defend against the attack, or the central bank would sell foreign currency to support the exchange rate.

An MPI was constructed for Indonesia, Korea and Thailand. Thailand and Korea were chosen for comparison since they, like Indonesia, experienced macroeconomic problems and intense attacks on their currencies, which forced them to seek IMF programs in $1997 .^{9}$

\section{Explanatory Variables}

To decompose the causes of the severe crisis in Indonesia, a number of domestic and foreign fundamentals were investigated. ${ }^{10}$ The domestic variables considered were of three kinds: financial (private claims to GDP, domestic credit to GDP, foreign liabilities to GDP, foreign assets to M1 and interest rate spread), ${ }^{11}$ non-financial (trade balance and terms of trade) and political (confidence in the political system and policies). Private claims to GDP and domestic credit to GDP measure the lending activity of the banking system. ${ }^{12}$ An rapid increase in these ratios could signify a growing strain of the banking system. ${ }^{13}$ These

${ }^{8}$ See e.g. Eichengreen, Rose, and Wyplosz (1996), Sachs, Tornell, and Velasco (1996), Frankel and Rose (1996) and Kaminsky, Lizondo, and Reinhart (1997) for similar constructions of exchange rate pressure.

${ }^{9}$ In addition, Granger Causality tests indicate that there is causality from Korea and Thailand to Indonesia, but not the other way around.

${ }^{10}$ The sources and construction of all variables are provided in the data appendix.

${ }^{11}$ IMF (1997a) and IMF (1997b) outlined concerns about the soundness of the banking sector just prior to the onset of the crisis.

${ }^{12}$ Hardy and Pazarbasioglu (1998) find a persistent tendency for credit to the private sector to follow a boom and bust pattern in advance of banking crises, with a further decline in credit growth during the crisis. Sachs, Tornell, and Velasco (1996), Radelet and Sachs (1998b) and Corsetti, Pesenti, and Roubini (1998b) also use this variable as a measure of a bank lending boom. They argue that this measure proxies for financial fragility, as the quality of bank loans is likely to deteriorate significantly when bank lending grows at a rapid pace in a relatively short period of time. Kaminsky and Reinhart (1996) find that the growth in domestic credit to GDP accelerates steadily and markedly as the crisis approaches, peaking at the time the crisis erupts.

${ }^{13}$ In Indonesia's case, domestic credit to GDP consists mainly of claims on the private sector. Net claims on the government are negative, indicating that the government was a net creditor. The inclusion of the central bank may be important in Indonesia's case since the 
variables are intended to account for a possible boom and bust lending cycle associated with the crisis countries: financial inflows in previous years had been channeled into the property market, stock market, and the corporate sector with decreasing profitability. ${ }^{14}$ We also included variables intended to measure foreign exchange exposure risks in the financial sector. The ratio of foreign liabilities to GDP measures the extent to which the banking system relies on foreign capital to fund its operations; hence, it proxies for the banking system's vulnerability to a sudden reversal of capital inflows. The ratio of foreign assets to M1 measures the degree to which foreign assets of the banking system back the M1 money supply. The interest rate spread is the difference between bank lending and deposit rates. It is an indicator of the profitability of the banking system. A deterioration of the trade balance may indicate an overvalued exchange rate leading to slow export growth and increased import growth. An adverse terms of trade shock may affect the competitiveness of the economy, and lead to deterioration of corporate sector profitability. The political confidence index is a measure of investors' confidence in the political stability of the economy. An increase reflects greater confidence, which may encourage capital inflows.

The external fundamentals include U.S. and Japanese rates of interest and the dollaryen exchange rate. The U.S. rate of interest is a proxy for the world interest rate. Lower world interest rates reduce pressure on the exchange rate as capital flows from industrial countries to developing countries in search of relatively higher returns. The Japanese interest rate is also used, since monetary conditions in Japan are believed to have contributed to the Asian crisis. In addition, swings in the dollar-yen exchange rate may have affected export competitiveness of countries pegged to the dollar.

\section{OLS and Probit Tests}

The main practical drawback of Markov-switching models is the difficulty of obtaining convergence when too many variables are included in the econometric

central bank was a source of subsidized credit to the agricultural sector and public enterprises. For some Latin American country studies, net domestic credit of the central bank may be the most useful variable, as it would reflect the financing of government expenditure similar to the first generation speculative attack models. However, it is less relevant for Indonesia, which did not have budget problems in the years preceding the crisis. The total domestic credit from the central bank and deposit money banks gives an overall measure of lending activity of the entire banking system to the domestic economy.

${ }^{14}$ Claessens, Djankov, and Lang (1998) find that while investment rates were high, corporate profitability in most East and Southeast Asian countries declined sharply in the years 19941996 and leverage increased. In Indonesia, profitability measured by real return on assets declined from 12.8 percent in 1990 to 4.9 percent in 1996. This data, while instructive, is unfortunately annual. We are not aware of high frequency data on corporate profitability for Indonesia. 
specification. ${ }^{15}$ Therefore, in order to obtain a parsimonious specification, we first used ordinary least squares and probit estimation to suggest the statistically relevant economic fundamentals from the set of variables believed to be important in the Asian crisis. To avoid endogeneity problems, the MPI for Indonesia is regressed on lags of the domestic and foreign fundamentals. ${ }^{16}$ The OLS results are shown in Table 1 . The four significant variables are domestic credit to GDP, foreign liabilities to GDP, private claims to GDP, and political confidence. The insignificant variables were dropped sequentially from the equation and the final specification contains foreign liabilities to GDP, private claims to GDP, and the political confidence index.

We also estimate a probit model following the methodology used in the literature (especially Eichengreen, Rose and Wyplosz (ERW) (1996)). The probit model uses a discrete dependent variable, and permits estimation of the probability of a speculative attack. The discrete dependent variable is constructed as follows (using the definition of a crisis or speculative attack as in ERW (1996)):

DUMMPIx $=1$ if MPIx $>\mu_{\mathrm{MPIx}}+1.5^{*} \sigma_{\mathrm{MPIx}}$

where $x$ denoted IDN, KOR and THA for Indonesia, Korea and Thailand, respectively, $\mu$ denotes the mean, and $\sigma$ denotes the standard deviation. According to this definition, there were only four time periods when Indonesia faced a crisis.

The results from the probit models are shown in Table 1. Column 3 contains estimates using lagged fundamentals (foreign liabilities, political confidence and private claims to GDP) as explanatory variables. The ratio of private claims to GDP and the ratio of foreign liabilities to GDP are significant. In column 4, the probit model is estimated with lagged dummy indicators of crises in Korea and Thailand in addition to the fundamentals. The coefficients on private claims to GDP and the probability of a crisis in Thailand are significant, the sign on the latter suggesting that exchange market pressure in Thailand led to pressure in Indonesia. The sign on private claims to GDP is counter to expectations in the probit and OLS models. The negative sign is more consistent with reduced vulnerability due to financial deepening than to increased vulnerability from a rapid buildup of credit. The other significant signs conform to expectations. In order to see if contagion (from crises in Korea and Thailand) contributed to the crisis in Indonesia, a Likelihood Ratio Test was performed on the results of columns 3 and 4 . The test indicates the joint significance (at the 5

${ }^{15}$ Numerical methods are used to find maximum likelihood estimates.

${ }^{16}$ For example, movements in the explanatory variables may result from valuation effects related to exchange rate changes, or may reflect the economic consequences of a major devaluation. 
percent level) of the two regional variables in the probit model. This indicates that contagion from the neighboring countries was important. ${ }^{17}$

\section{E. Markov-Switching Models}

Since ordinary least squares and probit estimation methods can easily accomodate many explanatory variables, the previous section was useful in gauging the overall statistical importance of different variables. However, this section turns to Markov-switching models (MSMs), which have several theoretical advantages in comparison to one or both of these other methods. ${ }^{18}$

In contrast to OLS and probit models, MSMs allow for nonlinear behavior, that is, behavior that varies depending on the state. MSMs, like probit models, can provide an

${ }^{17}$ The fitted probabilities of a crisis from the probit models have been constructed for an earlier version of this paper (available upon request). The probit model with contagion was a slight improvement over the model with only fundamentals, but did not perform as well as the Markov-switching models in the latter part of the sample.

${ }^{18}$ For details about estimating these models, see Kim and Nelson (1999). Other approaches to MSMs have also been explored in the literature. Kim (1993) analyses the structural change in the regression model using a two-stage method based on a two-stage Maximum A Posteriori (MAP) decision rule. Instead of estimating the conditional probability of being in a particular state, $\mathrm{p}\left(\mathrm{s}_{\mathrm{t}}\right)$, Kim estimates a sequence of unobserved regimes, $\mathrm{s}_{\mathrm{t}}$, based on MAP decision rule. In the first stage, he optimizes the Bellman equation, which produces a sequence, $s_{t}$. In the second stage, he uses $s_{t}$ as a regressor, and estimates the Markov Switching Regression by OLS. Instead of the classical approach, Albert and Chib (1993) and McCulloh and Tsay (1994) use Bayesian approach. In the classical framework, the inferences about the unobserved Markov Switching variables are made conditional on the parameter estimates. However, the Bayesian analysis treats the parameters and the Markov-switching variables as random variables. Hence, inferences about the state are made on a joint distribution via the simulation tool of Gibbs sampling, and not a conditional one as in the classical approach. This approach requires some amount of prior information to identify the parameters of the model. McCulloh and Tsay (1994) estimate the most general forms of these models and show that the uncertainty about the state of a specific time period will depend on the prior beliefs, hence the results become very sensitive to how the model is specified. Cooper (1998) uses a regression tree analysis to locate splits in the data, if they exist, rather than imposing a splitting point a priori. This approach has an advantage in that non-linearities can be analyzed along multiple dimensions, while no assumptions are necessary about the distributional properties of regime changes. But the drawback of this approach is that there is no formal means of testing the significance of individual splits. 
explicit measure of the probability of a crisis, while OLS does not. ${ }^{19}$ However, the creation of a discrete dependent variable in probit models involves an arbitrary cut-off in the underlying MPI in defining a period of crisis. In the Indonesian data, the conversion of the MPI to a discrete measure of crisis for the probit models results in only four cases of crisis. The process of creating a discrete variable leads to a loss of information on the magnitude of speculative attack (e.g. the data shows numerous incidents of pressure on the currency of varying degree). The exclusion of incidents of speculative pressure on the exchange rate below the arbitrary threshold value has the further disadvantage of introducing sample bias into the estimation procedure. Flood and Marion (1998) argue that many models of speculative attack indicate that unanticipated devaluations produce the largest jump in the MPI. The size of jumps in the MPI at the time of attack is reduced by the extent to which the attack is anticipated. Thus, selection of only extreme values of the MPI (as in construction of the dependent variable for probit models) may reduce the share of predictable crises in the sample and reduce the number of crises that are likely to be correlated with fundamental economic determinants. On the contrary, estimation of MSMs permits full use of the continuous dependent variable while endogenously determining the probability of a switch in regime. We now turn to MSMs to endogenize the probability of a crisis in Indonesia.

\section{Fixed transition probability model}

The fixed transition probability (FTP) MSM estimates the switch in mean of the MPI of Indonesia in the two states (high pressure indicating a crisis state and low pressure a noncrisis state). The model filters the data into states of high and low pressures and estimates the probabilities accordingly. The estimated model consists of a measurement equation with mean switching, and fixed transition probabilities:

$$
\begin{aligned}
& M P I_{t}-\mu_{s_{t}}=\phi\left[M P I_{t-1}-\mu_{s_{t-1}}\right]+\sum_{i=1}^{3} \beta_{i} F_{i, t-1}+e_{t} \\
& \mu_{s_{t}}=\left(1-s_{t}\right) \mu_{0}+s_{t} \mu_{1}, \quad e_{t} \sim \operatorname{iidN}\left(0, \sigma^{2}\right) \\
& \operatorname{Pr}\left(s_{t}=0 / s_{t-1}=0\right)=q, \quad \operatorname{Pr}\left(s_{t}=1 / s_{t-1}=1\right)=p
\end{aligned}
$$

where the MPI follows an AR(1) process ${ }^{20}$ and has two means ( $\mu_{0}$ low pressure and $\mu_{1}$ high pressure); $F_{i}$ consist of the predetermined fundamental variables suggested by the final OLS

${ }^{19}$ It should be noted that Markov-switching models rely on maximum likelihood estimation and typically assume normally distributed errors, putting these models (like probit models) at risk for this form of specification error.

${ }^{20}$ In order for the AR process to be stationary, $|\phi|<1$ is assumed. Indeed, standard unit root tests easily rejected the unit root hypothesis for the MPI. We also ran the MSM models (FTP and TVTP) with higher order autoregressive lags (2,3 and 4). Higher order lags were 
specification: political confidence, forliabgdp, and pvtclaimgdp; $p$ is the probability of remaining in a crisis state between times $\mathrm{t}-1$ and $\mathrm{t}$; $\mathrm{q}$ is the probability of remaining in a nocrisis state; and $s_{t}$ is the unobserved state. ${ }^{21}$

There are two types of figures shown for the Markov-switching models. The figures containing the probability of a crisis compare the actual data at time $t, M P I D N$, and the onestep ahead probability of a crisis $\left(\operatorname{Pr}\left(S_{t}=1 / M P I I D N_{t-1}\right)\right)$. The figures containing the forecasted values compare the actual data, $\operatorname{MPIIDN}_{\mathrm{t}}$, and the conditional expectation at time $\mathrm{t}-1,\left(E_{t-1} M P I I D N_{t}\right)$. Construction of forecasted values is described in Appendix $2{ }^{22}$

Figures 1a and $1 \mathrm{~b}$ show the MPI for Indonesia, one-step ahead probability of a crisis in Indonesia, and the forecasted MPI for Indonesia. Figure 1a shows that the dependent variable (Indonesia's MPI) indicates the occurrence of crises in 1997 and early 1998, but does not indicate incidents of significant pressure on the currency in any earlier periods. The spikes in the one-step ahead probabilities occur one period after the crisis. Figure $1 \mathrm{~b}$ shows the forecasted MPI for Indonesia from FTP MSM. The values are concentrated around zero up until 1997 , as the probability of going to a high state (1-q) is very low. Also, the spikes in the forecasted values occur one period after the actual data.

The coefficient estimates are summarized in the first column of Table 2 . The estimates of $\mathrm{q}$, phi, variance, mul and the coefficient on political confidence are significant. The high value of $q$ (close to 1 ) depicts a lot of persistence in the no-crisis state. The coefficient on political confidence is negative indicating that decreasing confidence in the political environment is associated with an increase in speculative pressure. The coefficients on forliabgdp and pvtclaimgdp have the expected signs, although they are insignificant. The estimate of $q$ is most significant, followed by the variance and $\mu_{1}$.

\section{Time-varying transition probability model with regional contagion}

To see if the exchange market pressures in Indonesia could be explained by movements in MPIs of Thailand and Korea after controlling for the fundamentals, a time-

insignificant in the FTP model and did not produce any difference in the results (quantitatively and statistically). No convergence was achieved for TVTP models that included higher order autoregressive processes.

${ }^{21}$ As a sensitivity test, we attempted to put the three domestic variables into the transition probabilities, and separately tried using the entire original set of fundamental variables in the measurement equation, but convergence was not achieved in either case.

${ }^{22}$ The forecasted values of MPIIDN are constructed using the parameters estimated over the entire sample, the predetermined explanatory variables and one-step ahead probability of switching to the high state in the next period. 
varying transition probability (TVTP) Markov-switching model is estimated. ${ }^{23}$ In this model, the probability of a crisis in Indonesia varies in the high and low states according to one period lags of the MPIs of Thailand and Korea. The transition probabilities are given by:

$$
\begin{aligned}
& \operatorname{Pr}\left(s_{t}=1 / s_{t-1}=1\right)=p_{t}=\frac{\exp \left[p_{0}+p_{1} M P I_{j, t-1}+p_{2} M P I_{k, t-1}\right]}{\left(1+\exp \left[p_{0}+p_{1} M P I_{j, t-1}+p_{2} M P I_{k, t-1}\right]\right)} \\
& \operatorname{Pr}\left(s_{t}=0 / s_{t-1}=0\right)=q_{t}=\frac{\exp \left[q_{0}+q_{1} M P I_{j, t-1}+q_{2} M P I_{k, t-1}\right]}{\left(1+\exp \left[q_{0}+q_{1} M P I_{j, t-1}+q_{2} M P I_{k, t-1}\right]\right)}
\end{aligned}
$$

where $\mathrm{MPI}_{\mathrm{j}, \mathrm{t}-1}$ and $\mathrm{MPI}_{\mathrm{k}, \mathrm{t}-1}$ are the lagged MPI for Thailand and Korea, respectively, and $\mathrm{p}$ and $q$ are varying over time in response to movements in these MPIs.

Figure 2a shows the actual MPI and one-step ahead probability of a crisis in Indonesia when the probability is a function of lagged Thai and Korean MPIs. It is clear from these figures that when the neighboring countries' market pressure indexes are accounted for, there is considerably more variation in the estimated probabilities. In addition, the crises are picked up with much greater accuracy in a TVTP and without delays. ${ }^{24}$ The probability of a crisis (pr(crisis)) peaks very close to one at the same time as the actual data in autumn 1997 and again in early 1998 . The simultaneous peaking is equivalent to prediction because the comparison at each point in time is between the actual data at time $t, M_{P I I D N}$, and the onestep ahead probability of a crisis $\left(\operatorname{Pr}\left(S_{t}=1 / M P I I D N_{t-1}\right)\right)$. In fact, there were two other occasions of spikes in the pr(crisis) earlier in 1997. Although the crisis did not happen in those same months, these points could be thought of as early warnings. Thus, including both fundamental variables and MPIs from Thailand and Korea, the MSMs can predict periods of crisis in 1997 and 1998. In contrast, analogous probit models from initial testing exercises had relatively poor results in predicting these crises. On the other hand, the TVTP MSMs have performed relatively poorly in the sense of indicating too many potential crises in earlier years that did not occur. Figure $2 b$ depicts the forecasted values from this model. The forecasted values overestimate the actual data during the earlier "tranquil" periods, since the probability of switching to the higher (crisis) state averages around 0.25 during this time.

${ }^{23}$ Diebold, et al (1994) and Filardo (1994) have used these models to examine business cycles.

${ }^{24}$ Other studies have confirmed the result that TVTP models perform better than FTP models. For example, Filardo (1994) uses a TVTP model to estimate the probabilities of expansion and recessions in US business cycles. With its extra flexibility and non-linear structure, the TVTP model appears to capture and predict accurately the expansions and contractions of monthly U.S. output data. Diebold, et al (1995) develop an algorithm to estimate a TVTP model and prove its superiority over a FTP model through a simulation exercise. 
The second column of Table 2 shows the parameter estimates from this model. In addition to the same significant parameters as in the FTP model, mu0, q1 and q2 are significant. The negative signs on $q 1$ and $q 2$ show that as speculative pressure mounts on Thai and Korean currencies, the probability of remaining in a no-crisis state in Indonesia declines and the chance of moving to a crisis state rises. The Likelihood Ratio Test shows the joint significance of the p's and q's at the 1 percent level of significance, suggesting the importance of Thai and Korean MPIs in predicting a crisis in Indonesia. Thus, there is evidence of contagion from the crises in Thailand and Korea.

Attention should be drawn to one additional point regarding the MSM results. The MSMs predict state shifts in the mean of the MPI. Although these state dependent means were not specified a priori, the model endogenously estimates them. In these MSMs, the estimates for the low state mean are slightly below the simple mean of the MPIIDN over the sample, while the estimated values of the high state means are very high, at about $81 / 2$ and 10 . The actual data on MPIIDN only attains these high values in 1997, during the time when any reasonable definition would indicate that a crisis occurred. Therefore, the probability of having the high state mean could be reinterpreted as the probability of having a mean so high as to be equivalent to "crisis".

\section{Contagion In The Stock MARKeT}

One drawback in the choice of monthly data for the analysis is that there are relatively few episodes of crisis. However, given the unavailability of high frequency data on economic variables including reserves and the variables used as fundamentals, the choice of monthly data for the exchange rate analysis was unavoidable. Nonetheless, this section turns to high frequency data stock market data, which although not permitting the use of controlling factors, contains a substantial number of observations over the entire crisis period.

Another motivation for investigating contagion in stock price data comes from the observed daily comovement of the exchange rate and stock market index (SMI) in Indonesia. The currency crisis in Indonesia was accompanied by a sharp drop in the stock market in August 1997, followed by considerable covariance. This observation is consistent with a movement out of Indonesian financial and Rupiah-denominated assets. Inspection of the daily movements in SMIs in Indonesia, Korea and Thailand also suggests that the three stock markets have been moving together in the crisis period.

To formally test for contagion in stock market, similar FTP and TVTP models are estimated for Indonesia's stock market index (in changes). While fundamental controlling variables are not included, the TVTP models contain lagged changes of Thai and Korean stock market indices in the transition probabilities. Figures $3 \mathrm{a}$ and $3 \mathrm{~b}$ show results from FTP models, while Figures $4 \mathrm{a}$ and $4 \mathrm{~b}$ show those for TVTP models. The estimates of $\mathrm{p}, \phi$, variance and $\mu_{0}$ are significant in both models, while $\mu_{1}$ is significant only in TVTP model. Although the p's and q's are individually insignificant, the Likelihood Ratio Test shows that 
the SMIs for Korea and Thailand are jointly significance in explaining changes in the state of the Indonesian SMI at the 5 percent level. Thus, there is evidence of contagion in stock market prices also. Moreover, the fitted values for the TVTP model track the actual data exceptionally close.

\section{Conclusions}

The chief objective of this paper has been to examine the causes of the exchange rate crisis in Indonesia. The causes explored fall into three broad categories: (i) domestic factors, including non-financial and financial fundamentals, and political risks; (ii) external shocks common to the Asian countries; and (iii) contagion from crises in the region. The latter factor is meant to gauge shifts in market sentiment that is unexplained by other macroeconomic fundamentals.

There may be some difficulty in distinguishing pure contagion from unobserved spillovers from neighboring countries or unobserved common global shocks. The two most likely spillovers include either trade linkages or financial linkages. If a neighboring country has a devaluation, the home country's exports may slow due to slackening demand from the neighbor or third countries (due to export competition with the neighbor); likewise, imports from the neighbor may increase owing to the price effect. These trade linkages may lead to deterioration of the home country's trade balance. There could also be direct financial linkages between the countries. Financial institutions in the home country may have a credit exposure or equity stakes in corporations, financial institutions, or real estate in the neighboring country. A crisis in the neighbor could then spillover by causing weakness in the home country's financial sector. While this paper does not control for direct spillovers from Thailand and Korea, it includes variables such as Indonesia's trade balance, and various financial indicators, which should respond to linkages with neighbors, among other things. An attempt was also made to control for common global shocks by including international variables such as U.S. and Japanese interest rates.

Results from econometric analysis suggest that domestic financial conditions, political confidence, and contagion from the region were all instrumental in causing Indonesia's crisis. In particular, Markov-switching models show that exchange rate pressure in Thailand and Korea helped predict subsequent exchange rate pressure in Indonesia. Likewise, stock market changes in Thailand and Korea helped predict stock market movements in Indonesia. 
Table 1: Results from Ordinary Least Squares and Probit Models

\begin{tabular}{|c|c|c|c|c|}
\hline & \multicolumn{2}{|c|}{ OLS Results } & \multicolumn{2}{|c|}{ Probit Results } \\
\hline & MPIIDN & $\begin{array}{c}\text { MPIIDN } \\
\text { Final } \\
\text { Specification }\end{array}$ & DUMMPIIDN & DUMMPIIDN \\
\hline Constant & $\begin{array}{l}0.915 \\
3.249 * *\end{array}$ & $\begin{array}{l}0.170 \\
1.260\end{array}$ & $\begin{array}{l}-2.408 \\
-6.631\end{array}$ & $\begin{array}{l}-2.613 \\
-5.915\end{array}$ ** \\
\hline AR(1) & $\begin{array}{l}-0.080 \\
-0.772\end{array}$ & $\begin{array}{l}-0.034 \\
-0.358\end{array}$ & & \\
\hline DUMMPIKOR(-1) & & & & $\begin{array}{l}1.870 \\
0.638\end{array}$ \\
\hline DUMMPITHA(-1) & & & & $\begin{array}{l}1.621 \\
2.047 * *\end{array}$ \\
\hline DOMCRGDP(-1) & $\begin{array}{l}-17.649 \\
-2.880\end{array}$ & & & \\
\hline FORLIABGDP(-1) & $\begin{array}{c}15.333 \\
4.308\end{array}$ & $\begin{array}{c}12.153 \\
3.898 \text { * }\end{array}$ & $\begin{array}{l}1.555 \\
3.006 * *\end{array}$ & $\begin{array}{l}0.935 \\
1.319\end{array}$ \\
\hline FA2M1(-1) & $\begin{array}{l}-1.540 \\
-0.852\end{array}$ & & & \\
\hline POLCONF(-1) & $\begin{array}{l}-0.634 \\
-3.967 * *\end{array}$ & $\begin{array}{l}-0.351 \\
-2.973 \text { ** }\end{array}$ & $\begin{array}{l}-0.156 \\
-0.943\end{array}$ & $\begin{array}{l}0.004 \\
0.015\end{array}$ \\
\hline PVTCLAIMGDP(-1) & $\begin{array}{l}-4.788 \\
-2.528=\end{array}$ & $\begin{array}{l}-4.893 \\
-2.940\end{array}$ & $\begin{array}{l}-8.459 \\
-2.992 * *\end{array}$ & $\begin{array}{l}-6.543 \\
-1.798\end{array}$ \\
\hline RTSPREAD(-1) & $\begin{array}{l}0.283 \\
0.962\end{array}$ & & & \\
\hline $\mathrm{TB}(-1)$ & $\begin{array}{l}0.047 \\
0.088\end{array}$ & & & \\
\hline TOT(-1) & $\begin{array}{l}0.001 \\
0.134\end{array}$ & & & \\
\hline JPNRROI(-1) & $\begin{array}{l}0.633 \\
0.850\end{array}$ & & & . \\
\hline USRROI(-1) & $\begin{array}{l}0.535 \\
0.699\end{array}$ & & & \\
\hline JAPANUSEXRT(-1) & $\begin{array}{l}0.002 \\
0.063\end{array}$ & & & \\
\hline R-squared & 0.212 & 0.157 & & \\
\hline Likelihood Value & & & -11.478 & -7.938 \\
\hline Likelihood Ratio 1/ & & & 7.1 & \\
\hline Critical Value 2/ & & & $4.6,6$. & $0,9.2$ \\
\hline Sample Period & $86: 7$ to $98: 3$ & $85: 1$ to $98: 3$ & $85: 1$ to $98: 4$ & $85: 2$ to $98: 4$ \\
\hline No. of Observations 31 & 141 & 159 & 160 & 159 \\
\hline
\end{tabular}

Note: The figures below the coefficients are !-statistics. " and "denote the significance at

5 and $10 \%$, nespectively

$1 / 2^{*}\left(L R_{U R}-L R_{R}\right)-x^{2}$ d.t. where d.f, is the number of restrictions

$2 /$ At the 10,5 , and 1 percent levels, respectively

$3 /$ For Probit models, the number of coservations with Dependent Variable $=1$ is 4 
Table 2: Results from Markov Switching Models

\begin{tabular}{|c|c|c|c|c|}
\hline & \multicolumn{2}{|c|}{ MPIIDN } & \multicolumn{2}{|c|}{ SMIIDN } \\
\hline & $\overline{\text { FTP }}$ & TVTP & $\overline{\text { FTP }}$ & TVTP \\
\hline$p$ & $\begin{array}{l}0.331 \\
1.225\end{array}$ & $\begin{array}{l}0.000 \\
0.000\end{array}$ & $\begin{array}{c}0.951 \\
55.400\end{array}$ & $\begin{array}{c}1.000 \\
348.42\end{array}$ \\
\hline $\mathbf{q}$ & $\begin{array}{c}0.987 \\
107.99\end{array}$ & $\begin{array}{c}1.000 \\
11111\end{array}$ & $\begin{array}{l}0.188 \\
1.500\end{array}$ & $\begin{array}{l}0.000 \\
0.017\end{array}$ \\
\hline phi & $\begin{array}{l}-0.167 \\
-2.100\end{array}$ & $\begin{array}{l}-0.284 \\
-2.930\end{array}$ & $\begin{array}{l}0.413 \\
5.820 \text { * }\end{array}$ & $\begin{array}{l}0.247 \\
3.660 * *\end{array}$ \\
\hline variance & $\begin{array}{c}1.087 \\
17.660^{\star \star}\end{array}$ & $\begin{array}{c}1.062 \\
17.510\end{array}$ & $\begin{array}{c}2.267 \\
18.280 \text { * }\end{array}$ & $\begin{array}{c}2.678 \\
18.460\end{array}$ \\
\hline muo & $\begin{array}{l}-0.104 \\
-1.325\end{array}$ & $\begin{array}{l}-0.135 \\
-1.920\end{array}$ & $\begin{array}{l}-7.118 \\
-9.280 \text { * }\end{array}$ & $\begin{array}{l}-1.406 \\
-2.760\end{array}$ \\
\hline mu1 & $\begin{array}{c}9.816 \\
14.480 \text { ** }\end{array}$ & $\begin{array}{c}8.515 \\
15.830\end{array}$ & $\begin{array}{l}0.252 \\
1.012\end{array}$ & $\begin{array}{l}0.542 \\
1.700\end{array} *$ \\
\hline mpithap $(-1)$ & - & $\begin{array}{l}-0.740 \\
-1.057\end{array}$ & - & $\begin{array}{l}0.019 \\
0.196\end{array}$ \\
\hline mpithaq(-1) & $\begin{array}{l}- \\
-\end{array}$ & $\begin{array}{l}-0.195 \\
-1.709\end{array}$ * & - & $\begin{array}{l}0.344 \\
0.584\end{array}$ \\
\hline mpikorp(-1) & - & $\begin{array}{l}0.410 \\
0.727\end{array}$ & - & $\begin{array}{l}0.435 \\
1.255\end{array}$ \\
\hline mpikorq(-1) & - & $\begin{array}{l}-0.148 \\
-3.093\end{array}$ & - & $\begin{array}{l}-0.363 \\
-1.179\end{array}$ \\
\hline fliabgdp $(-1)$ & $\begin{array}{r}11.427 \\
0.554\end{array}$ & $\begin{array}{r}20.227 \\
1.004\end{array}$ & - & $\begin{array}{l}- \\
-\end{array}$ \\
\hline polconf $(-1)$ & 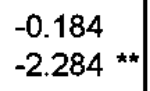 & $\begin{array}{l}-0.243 \\
-3.099\end{array}$ & - & - \\
\hline ptclmgdp(-1) & $\begin{array}{l}9.919 \\
0.882\end{array}$ & $\begin{array}{l}8.848 \\
0.806\end{array}$ & - & - \\
\hline Likfn. Val & 246.98 & 280.47 & 636.63 & 642.45 \\
\hline $\begin{array}{c}\text { LR 1/ } \\
\text { Critical Val2 }\end{array}$ & 7.8 .9 .5 & $5,13.3$ & $7.8,9$. & 13.3 \\
\hline
\end{tabular}

Note: The figures below the coefficients are the t-statistics. ** and * denote the significance of the coefficients at the 5 and $10 \%$ level of significance, respectively.

$1 / 2^{\star}\left(L R_{U R}-L R_{R}\right) \sim \chi^{2}$ d.f. where d.f. is the number of restrictions $2 /$ At the 10,5, and 1 percent levels, respectively 
Figure 1. Probabilities and Forecasts for Indonesia's Market Pressure Index Fixed Transition Probability Markov-Switching Model
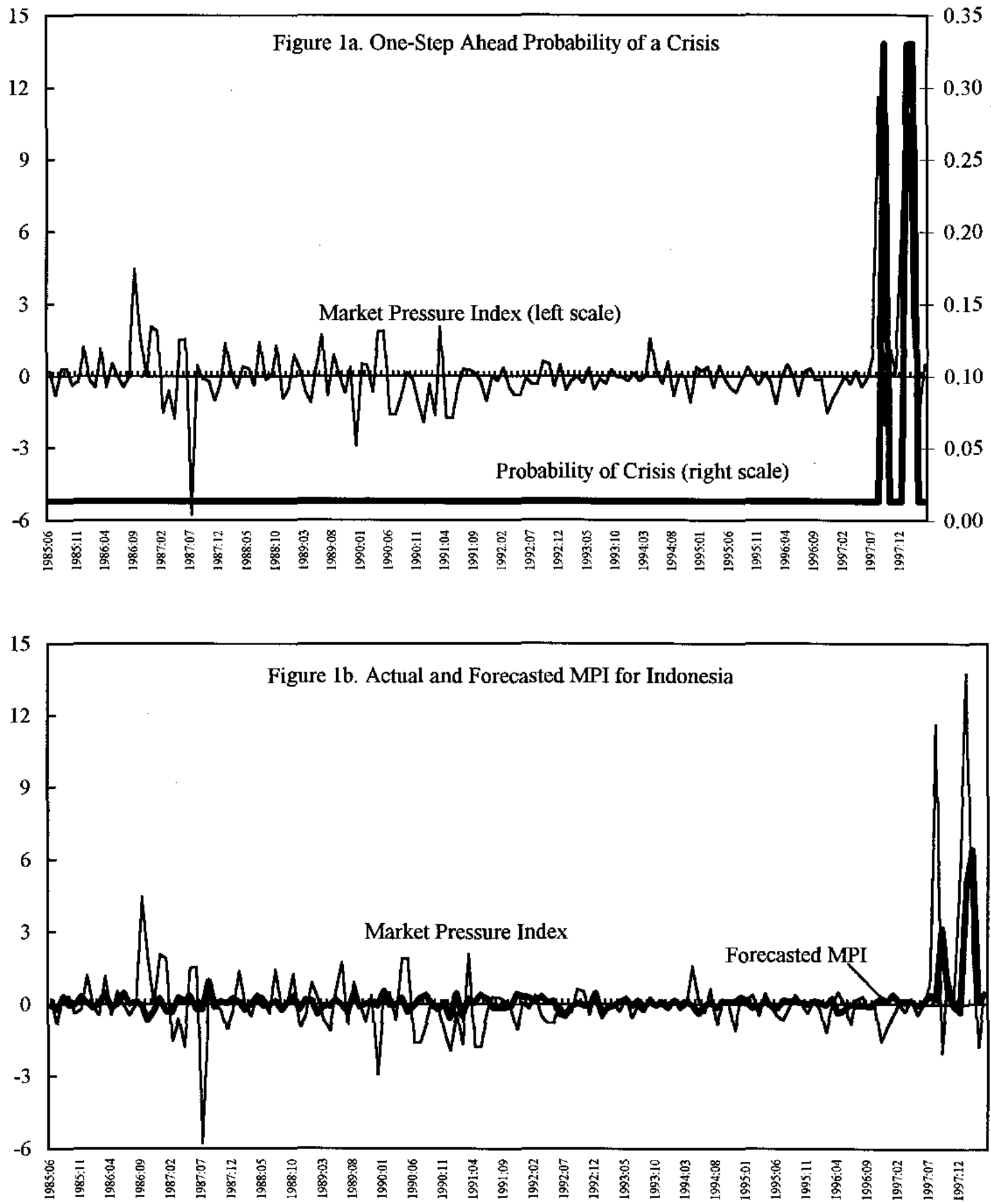

Sources: IFS and authors' calculations 
Figure 2. Probabilities and Forecasts for Indonesia's Market Pressure Index Time-Varying Transition Probability Markov-Switching Model
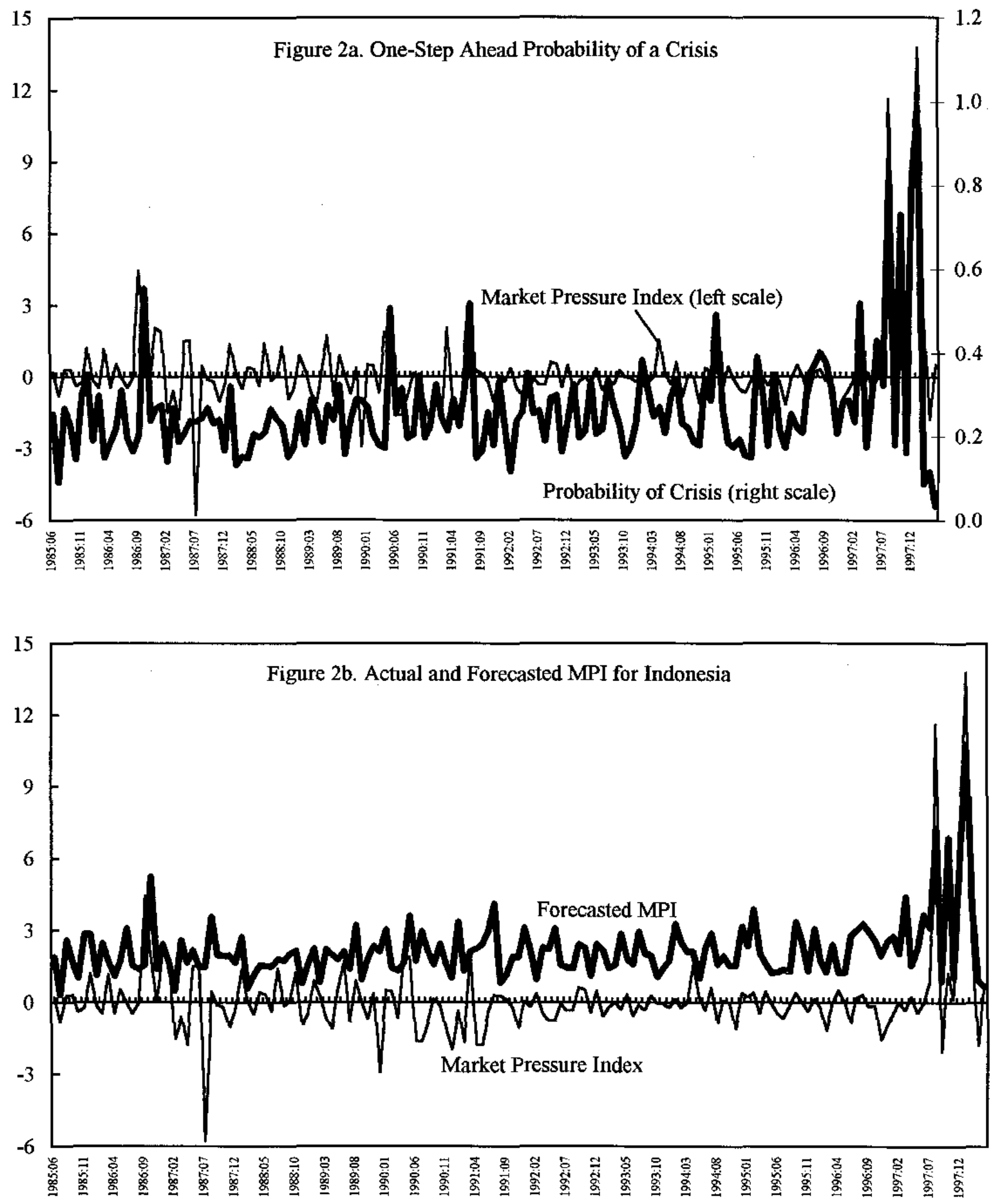

Sources: IFS and authors' calculations 
Figure 3. Probabilities and Forecasts for Indonesia's Stock Market Index

Fixed Transition Probability Markov-Switching Model
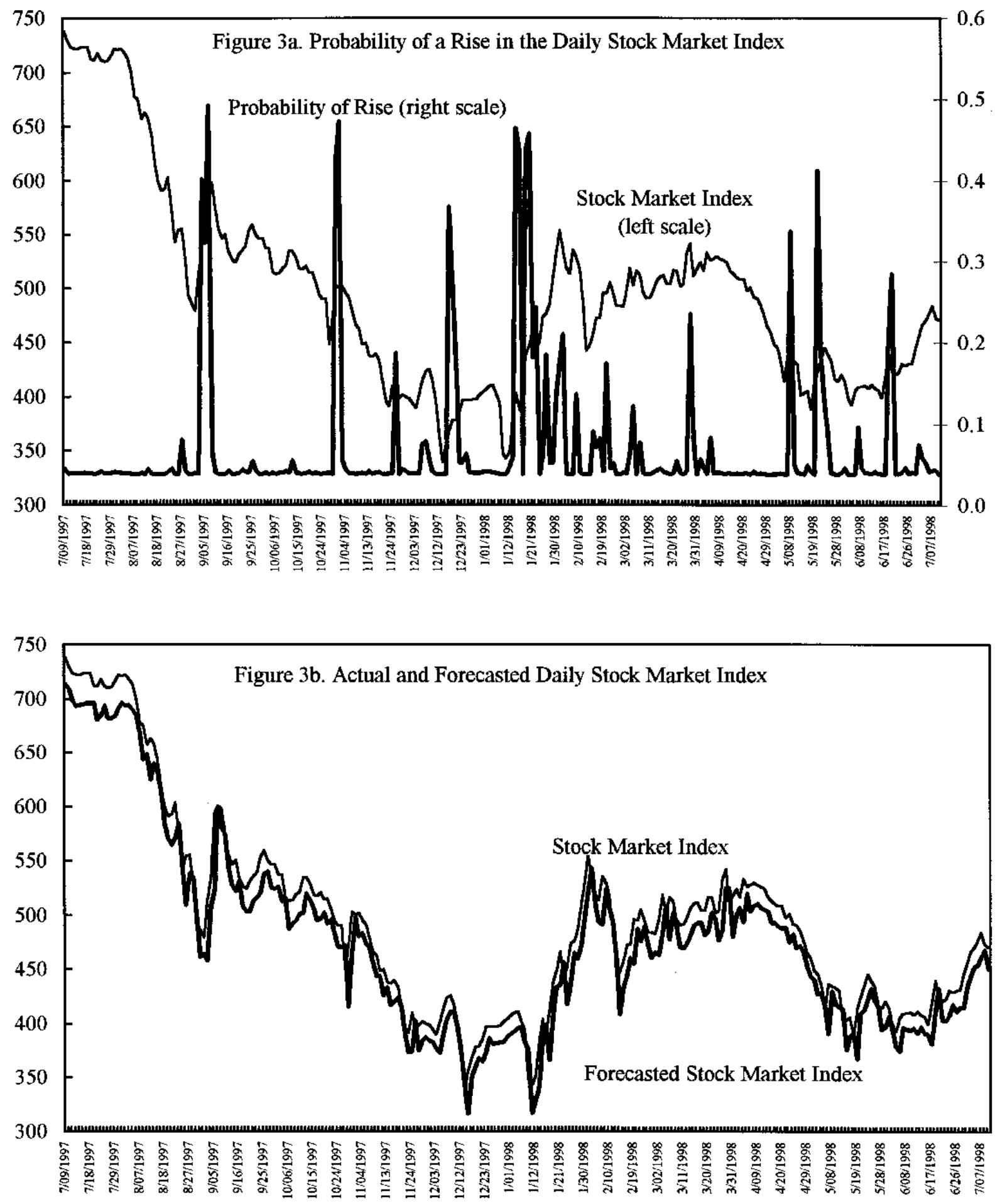

Sources: IFS and authors' calculations 
Figure 4. Probabilities and Forecasts for Indonesia's Stock Market Index Time-Varying Transition Probability Markov-Switching Model
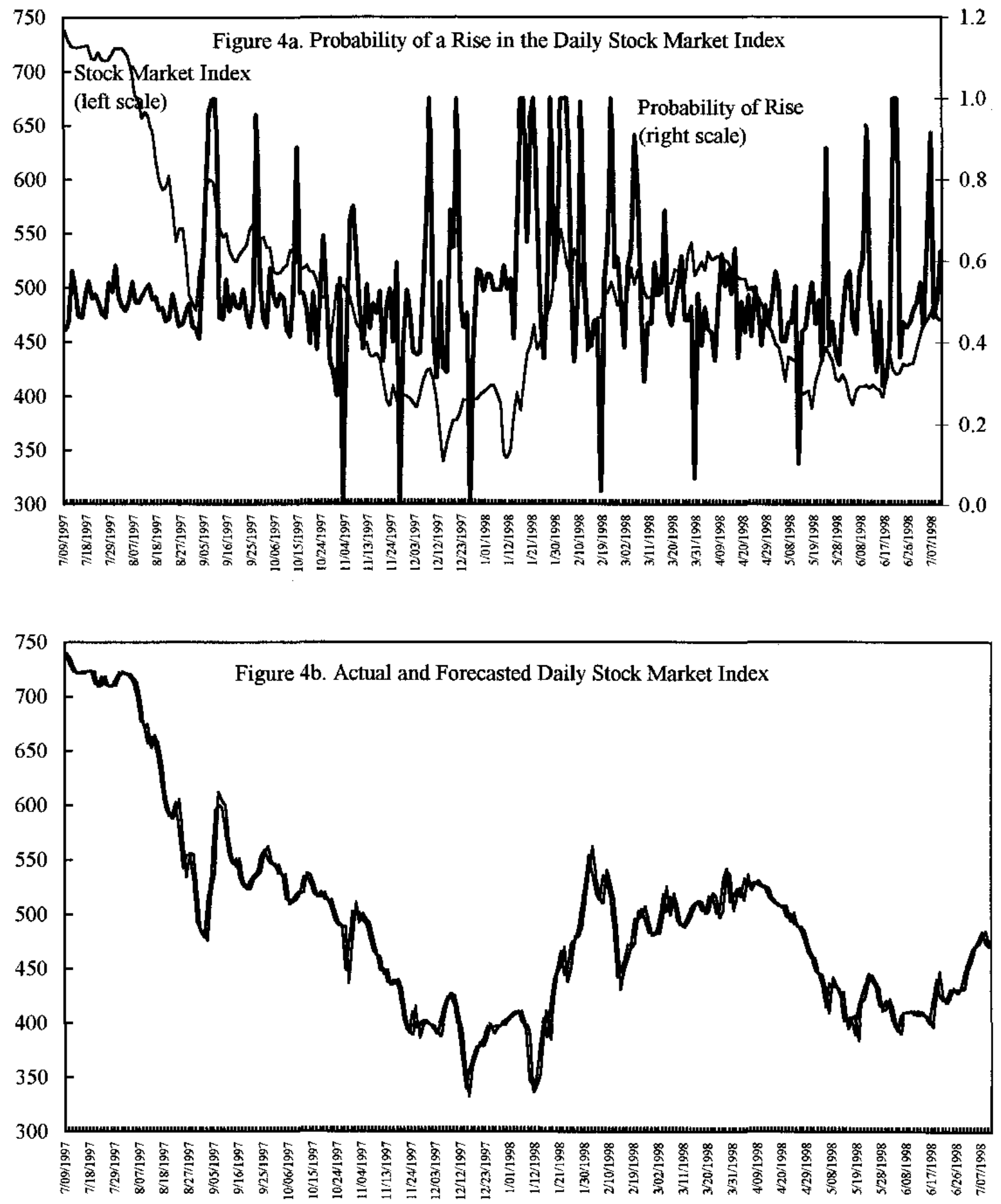

Sources: IFS and authors' calculations 


\section{Data Sources and Construction}

Date Sources:

\begin{tabular}{|l|l|l|}
\hline Variable & Description of the Variable & Source \\
\hline $\mathrm{e}$ & Average-period exchange rate & IFS line rf \\
\hline $\mathrm{i}$ & Discount-rate or money market rate & IFS line 60 or 60b \\
\hline $\mathrm{r}$ & Non-gold international reserves & IFS line 1ld \\
\hline REER & Real Effective Exchange Rate & IMF calculation \\
\hline gdp & Gross Domestic Product & $\begin{array}{l}\text { Indonesian Financial } \\
\text { Statistics, BI Publication }\end{array}$ \\
\hline forliab & Deposit money banks' gross foreign liabilities & IFS line 26c \\
\hline pvtcredit & Deposit money banks' credit to private sector & IFS line 22d \\
\hline domcr & Domestic Credit & IFS line 32 \\
\hline depliab & Real bank deposit liabilities & IFS line 24 + 25 \\
\hline M1 & M1 measure of money supply & IFS line 34 \\
\hline forasset & Deposit money banks' gross foreign assets & IFS line 21 \\
\hline rtspread & Difference between lend rate and deposit rate & IFS line 60P minus 60L \\
\hline polconf & Political confidence measure & Int'l Country Risk Guide \\
\hline exports & Exports & IFS line 70d \\
\hline imports & Imports & IFS line 71d \\
\hline xvalue & Unit price of export & IFS line 76 (updated from \\
& & Indonesian Financial \\
& & Statistics, Bl Publication) \\
\hline mvalue & Unit Value of import & Indonesian Financial \\
& & Statistics \&Import Statistika \\
\hline jpndisctrt & Japanese discount rate & IFS line 60 \\
\hline jpncpi & Japanese Consumer Price Index & IFS line 60 \\
\hline uscpi & U.S. Consumer price Index & IFS line 64 \\
\hline ustbillrt & U.S. 3-month treasury bill rate & IFS line 60 \\
\hline
\end{tabular}

\section{Data Construction:}

The Market Pressure Index (MPI) for Indonesia, Korea and Thailand was constructed as:

$$
M P I_{i, t}=\left(\% \Delta e_{i, t}\right) / \sigma_{\Delta e_{i, t}}+\left(\Delta i_{i, t}\right) / \sigma_{\Delta i_{i, t}}-\left(\% \Delta r_{i, t}\right) / \sigma_{\Delta r_{i, t}}
$$

where $e$ is the U.S. dollar exchange rate (domestic currency/US\$); $i$ is the discount rate; $r$ is the non-gold international reserves; $\sigma$ is the standard deviation of the respective series. Ratios were constructed as forliabgdp $=$ forliab/gdp; pvtclaimgdp $=$ private claims to GDP; forasset $2 \mathrm{ml}=\mathrm{fa} 2 \mathrm{ml}=$ forasset $/ \mathrm{ml}$; domcrgdp $=$ domcr $/ \mathrm{gdp}$; tradebalance $=\mathrm{tb}=$ exportsimports; TOT $=($ xvalue $/$ mvalue $) * 100$; usrroi $=$ ustbillrt - usinflation; jpnrroi $=$ jpndisctrt jpninflation. The measure on political confidence (polconf) was taken from ratings compiled every month by the PRS Group in the International Country Risk Guide. This indicator is weighted of government stability, socio-economic conditions, the investment profile, internal conflict, external conflict, corruption, military in politics, religion in politics, law and order, ethnic tensions, democratic accountability, and bureaucratic quality. 


\section{Construction of "Forecasted Values" for the Markov Switching Models}

The measurement equation for the simple Fixed Transition Probability Model is given by equation (1).

(1) $Y_{t}=\mu_{t}+\phi\left(Y_{t-1}-\mu_{t-1}\right)+\sum_{j=1}^{3} \beta_{\mathrm{j}} X_{j, t-1}+e_{t}$

where $Y_{t}=$ MPIIDN $_{t}$ and $\mu_{t}=\mu_{0}\left(1-S_{t}\right)+\mu_{1} S_{t}$

The expected value of $Y_{t}$ at time (t-1) can be found by taking the expectation of both sides of (1), conditional on information at $(\mathrm{t}-1)$.

$$
\begin{aligned}
E_{t-1} Y_{t} & =E_{t-1}\left[\mu_{0}-\mu_{0} S_{t}+\mu_{1} S_{t}\right]+E_{t-1}\left[\phi Y_{t-1}\right]-E_{t-1}\left[\phi \mu_{0}-\phi \mu_{0} S_{t-1}+\phi \mu_{1} S_{t-1}\right] \\
& +E_{t-1}\left[\sum_{j=1}^{3} \beta_{j} X_{j, t-1}\right]+E_{t-1}\left[e_{t}\right]
\end{aligned}
$$

The parameters $\mu_{0}, \mu_{1}$ and $\phi$ are constants. They are, therefore, independent of the state. We have the following conditional expectations:

$$
\begin{aligned}
& E_{t-1}\left[\mu_{i}\right]=\hat{\mu}_{\mathrm{i}} \quad(6) \quad E_{t-1}\left[\mu_{i} S_{t}\right]=\hat{\mu}_{\mathrm{i}} E_{t-1}\left[S_{t}\right] \mathrm{i}=0 \\
& E_{t-1}\left[\phi \mu_{i}\right]=\hat{\phi} \hat{\mu}_{i}+\operatorname{Cô} v\left(\phi, \mu_{i}\right) \quad \mathrm{i}=0,1 \quad \text { (8) } E_{t-1}\left[e_{t}\right]=0
\end{aligned}
$$

We can also find the conditional expectations of the state.

(9) $E_{t-1} S_{t-1}=\sum_{0,1} \mathrm{~S}_{\mathrm{t}-1} \operatorname{Pr}\left(S_{t-1} / Y_{t-1}\right)=\operatorname{Pr}\left(S_{t-1}=1 / Y_{t-1}\right)$ and (10) $E_{t-1} S_{t}=\operatorname{Pr}\left(S_{t}=1 / Y_{t-1}\right)$

Since the explanatory variables are pre-determined, we can find the conditional expectations by using the actual values of the lagged explanatory variables.

$$
E_{t-1}\left[\sum_{j=1}^{3} \beta_{j} X_{j, t-1}\right]=\sum_{j=1}^{3} \hat{\beta}_{j} X_{j, t-1}
$$

Substituting (5) through (11) into (4), we can get an expression for $E_{t-1} Y_{t}$ in terms of the parameter estimates $\mu_{0}, \mu_{1}$ and $\phi$, the off-diagonal elements of the parameter covariance matrix $\operatorname{Cov}\left(\phi, \mu_{0}\right)$ and $\operatorname{Cov}\left(\phi, \mu_{1}\right)$, the conditional probabilities in (9) and (10), and the lagged dependent and independent variables $Y_{t-1}$ and $X_{j, t-1}$.

$$
\begin{aligned}
& E_{t-1} Y_{t}=\hat{\mu}_{0}+\left(\hat{\mu}_{1}-\hat{\mu}_{0}\right) * \operatorname{Pr}\left(S_{t}=1 / Y_{t-1}\right)+\hat{\phi} Y_{t-1}-\left(\hat{\phi} \hat{\mu}_{0}+\operatorname{Cov}\left(\phi, \mu_{0}\right)\right)+ \\
& {\left[\hat{\phi} \hat{\mu}_{0}+\operatorname{Cov}\left(\phi, \mu_{0}\right)-\hat{\phi} \hat{\mu}_{1}-\operatorname{Cov}\left(\phi, \mu_{1}\right)\right]^{*} \operatorname{Pr}\left(S_{t-1}=1 / Y_{t-1}\right)+\sum_{j=1}^{3} \hat{\beta}_{j} X_{j, t-1}}
\end{aligned}
$$

Construction of forecasted values for the Time Varying Transition Probability Markov Switching Model in Figure $2 \mathrm{~b}$ are similar to above, except that the transition probabilities are affected by lagged values of MPIs in Thailand and Korea. 


\section{References}

Agenor, Pierre-Richard and Joshua Aizenman, 1997. "Contagion and Volatility with Imperfect Credit Markets", NBER Working Paper No. 6090.

Albert, J. and S. Chib, 1993. "Bayesian Inference via Gibbs Sampling of Autoregressive Time Series Subject to Markov Mean and Variance Shifts", Journal of Business and Economic Studies, 11, 1-15.

Berg, Andrew, 1998. "The Asian Crisis: Causes, Policy Responses and Outcomes", mimeo, International Monetary Fund.

Calvo, Guillermo, 1995, "Varieties of Capital Market Crises," Center for International Economics WP \# 16, University of Maryland at College Park.

Calvo, G., Leonardo Leiderman and Carmen Reinhart, 1993, "Capital Inflows and Real Exchange Rate Appreciation in Latin America: The Role of external factors," IMF Staff Papers 40(1), 108-51.

Calvo, Sara and Carmen Reinhart, 1995, "Capital Flows to Latin America: Is There Evidence of Contagion?", unpublished manuscript, World Bank and the IMF.

Cerra, Valerie and Sweta C. Saxena, 1998. "Contagion, Monsoons and Domestic Turmoil in Indonesia: A Case Study in the Asian Crisis", mimeo, International Monetary Fund.

Claessens, Stijn, Simeon Djankov, and Larry Lang, 1998. "East Asian Corporates: Growth, Financing and Risks over the Last Decade", mimeo, World Bank.

Cooper, S.J., 1998. "Multiple Regimes in US output fluctuations", Journal of Business and Economic Studies, 16(1), 92-100.

Corsetti, G, P. Pesenti and N. Roubini, 1998a. "What Caused the Asian Currency and Financial Crisis?", mimeo, NYU.

Corsetti, G, P. Pesenti and N. Roubini, 1998b. "Paper Tigers? A Model of the Asian Crisis", mimeo, NYU.

Diamond, Douglas W. and Philip H. Dybvig, 1983. "Bank Runs, Deposit Insurance and Liquidity", Journal of Political Economy, Vol. 91, No. 3, pages 401-19.

Diebold, F.X., J.H. Lee and G.C. Weinbach, 1994. "Regime Switching with Time-Varying Transition Probabilities", in Non-Stationary Time Series Analysis and Cointegration, edited by C. Hargreaves, Oxford University Press.

Eichengreen, Barry, Andrew Rose and Charles Wyplosz, 1996. "Contagious Currency Crises: First Tests", Scandinavian Journal of Economics, 98(4), 463-484.

Evans, M.D.D., 1993. "Estimating General Markov Switching Models", Discussion Paper, NYU, 93-02.

Filardo, Andrew J., 1994. "Business Cycle Phases and Their Transitional Dynamics", Journal of Business and Economic Statistic, July issue, 299-308.

Flood, Robert and Peter Garber, 1984. "Collapsing Exchange-Rate Regimes: Some linear Examples", Journal of International Economics, 17, pages 1-13.

Flood, Robert and Nancy Marion, 1998. "Perspectives on the Recent Currency Crisis Literature", IMF Working Paper, WP/98/130.

Frankel, Jeffery and Andrew Rose, 1996. "Currency Crashes in Emerging Markets: An Empirical Treatment", Journal of International Economics, Vol. 41(3-4), pages 35166. 
Frankel, Jeffery and Sergio Schmuckler, 1997, "Crisis, contagion, and country funds: Effects on East Asia and Latin America," in Managing Capital Flows and Exchange RatesPerspectives from the Pacific Basin, edited by Reuvin Glick, Cambridge Univ. Press.

Froot, Kenneth, David Scharfstein and Jeremy Stein, 1992. "Herd on the Street: Information Efficiencies in a Market with Short-Term Speculation", Journal of Finance, 47(4), September 1992, pages 1461-84.

Goldfajn, Ilan and Rodrigo Valdes, 1997. "Capital Flows and the Twin Crises: The Role of Liquidity", IMF Working Paper, WP/ 97/87.

Hamilton, James, 1994. Time Series Analysis, Princeton University Press.

Hardy, Daniel C. and Ceyla Pazarbasioglu, 1998. "Leading Indicators of Banking Crises: Was Asia Different", IMF Working Paper, WP/98/91.

Indonesian Financial Statistics, Bank Indonesia Publication, Various Issues.

International Monetary Fund, 1997a. Indonesia-Selected Issues, SM/97/159.

-.., 1997b. Indonesia - Recent Economic Developments, SM/97/163.

Kaminsky, Graciela, Saul Lizondo and Carmen Reinhart, 1997. "Leading Indicators of Currency Crises", IMF Working Paper, WP/97/79.

Kaminsky, Graciela and Carmen Reinhart, 1996. "The Twin Crises: The Causes of Banking and Balance of Payments Problems", International Finance Discussion Paper, Washington: International Monetary Fund.

Kim, Chang Jin and Charles R. Nelson, 1999. State Space Models with Regime Switching: Classical and Gibbs Sampling Approaches with Applications, MTT Press.

Kim, I.M., 1993. "A Dynamic Programming Approach to the Estimation of Markov Switching Regression Models", Journal of Statistical Computation and Simulation, 45, 61-76.

Kochhar, Kalpana, Prakesh Lougani, and Mark Stone, 1998. "The East Asian Crisis: Macroeconomic Developments and Policy Lessons", IMF Working Paper, WP/98/128.

Krugman, Paul, 1979. "A Model of Balance of Payments Crises", Journal of Money, Credit and Banking, 11, 311-25.

--------, 1998. "What happened to Asia?", mimeo, MIT.

Masson, Paul, 1998. "Contagion: Monsoonal Effects, Spillovers, and Jumps Between Multiple Equilibria", mimeo, IMF.

McCulloh, R.E. and R.S. Tsay, 1994. "Statistical Analysis of Economic Time Series via Markov Switching Models", Journal of Time Series Analysis, 15, 523-39.

Montiel, Peter J, 1997a. "The Theory of the Long-Run Equilibrium Exchange Rate", mimeo, Department of Economics, Williams College.

----, 1997b. "Exchange Rate Policy and Macroeconomic Management in ASEAN Countries", Chapter 11 in Macroeconomic Issues Facing ASEAN Countries, Edited by John Hicklin, David Robinson and Anoop Singh, IMF Publication.

Obstfeld, Maurice, 1986. "Rational and Self-Fulfilling Balance of Payments Crises", American Economic Review, Vol. 76, No. 1, pages 72-81.

Radelet, S. and Jeffrey Sachs, 1998a. "The Onset of the East Asian Financial Crisis", mimeo, Harvard Institute for International Development.

1998b. "The East Asian Financial Crisis: Diagnosis, Remedies, Prospects", mimeo, Harvard Institute for International Development. 
Sachs, Jeffrey, Aaron Tornell, and Andres Velasco, 1996. "Financial Crises in Emerging Markets: The Lessons of 1995", Brookings Papers on Economic Activity No. 1, 147217.

Saxena, Sweta, 1998. "A Country Report on Indonesia", in The Asian Crisis: What has happened and Why?", edited by Kar-yiu Wong, Department of Economics, University of Washington.

Saxena, Sweta, and Kar-yiu Wong, 1998. "Currency Crises and Capital Controls: A Selective Survey", mimeo, University of Washington.

Valdes, Rodrigo, 1996, "Emerging Markets Contagion: Evidence and Theory", unpublished manuscript, MIT, Cambridge, MA. 